\title{
REKAM JEJAK NARAPIDANA SEBELUM MASUK LEMBAGA PEMASYARAKATAN NARKOTIKA TANJUNGPINANG
}

\section{PRE RECORD PRISONERS NARCOTICS BEFORE ENTERING THE PRISONS OF TANJUNGPINANG}

\author{
Oksep Adhayanto \\ Universitas Maritim Raja Ali Haji \\ email : adhayantooksep@umrah.ac.id \\ Irman \\ Universitas Maritim Raja Ali Haji \\ email : irman@umrah.ac.id \\ Dwi Vita Lestari Soehardi \\ Sekolah Tinggi Agama Islam Negeri Sultan Abdurrahman Kepulauan Riau \\ email : dwi_vita@stainkepri.ac.id
}

\begin{abstract}
Tanjungpinang City is an area bordering a neighboring country that has experienced an increase in narcotics prisoners in the last 2 years. This study seeks to see the prisoners' track record before entering the Tanjungpinang narcotics prison which is then expected to contribute to the preparation of policies related to narcotics prevention, especially the prevention aspects by looking at the behavior of narcotics users. This type of research is a survey involving 258 respondents from 864 inmates in the Narcotics Prison. The research approach is used through a sociological approach and statute approach. The data source used is primary data using a questionnaire as a data collection tool. It is known that there are majority users of narcotics prisoners in Tanjung Pinang prison aged 16-40 years when they were first arrested with the majority article being imposed is Article 112 of Law No. 35 of 2009. Curiosity, an invitation from friends and environmental factors that cause prisoners in Tanjungpinang narcotics prison to fall into narcotics. Other activities undertaken by respondents besides consuming narcotics are smoking, alcoholic and free sex. Easily obtain cannabis and shabu-shabu types of narcotics because both types are circulated in accordance with the financial capabilities of the offender. Efforts to prevent and deal with narcotics can be done through strict repairs and supervision of the environment in the community and education and socialization of threats that apply in Law No. 35 of 2009.
\end{abstract}

\section{Keywor: Prisoners; Narcotics; Track Records}

\begin{abstract}
Abstrak
Kota Tanjungpinang merupakan daerah yang berbatasan dengan negara tetangga yang dalam 2 tahun terakhir mengalami peningkatan narapidana narkotika. Penelitian ini berupaya untuk melihat rekam jejak narapidana sebelum masuk ke lapas narkotika Tanjungpinang yang kemudian diharapkan dapat berkontribusi pada penyusunan kebijakan terkait dengan penanggulangan narkotika khususnya aspek pencegahan dengan melihat perilaku pengguna narkotika. Jenis penelitian yang digunakan adalah survey yang melibatkan 258 responden dari 864 narapidana yang ada di lapas narkotika Kota Tanjungpinang. Pendekatan penelitian yang digunakan
\end{abstract}


melalui sosiological approach dan statute approach. Sumber data yang digunakan adalah data primer dengan menggunakan kuisioner sebagai alat pengumpulan data. Diketahui bahwa terdapat pengguna mayoritas narapidana narkotika dilapas Tanjungpinang berusia 16-40 tahun ketika pertama kali ditangkap dengan pasal mayoritas yang dikenakan adalah pasal 112 UU No. 35 Tahun 2009. Rasa ingin tahu, ajakan teman dan faktor lingkungan yang menyebabkan narapidana dilapas narkotika Tanjungpinang terjerumus pada narkotika. Aktivitas lain yang dilakukan oleh responden selain mengkonsumsi narkotika adalah merokok, miras dan melakukan sek pra nikah. Mudahnya memperoleh narkotika jenis ganja dan sabu-sabu dikarenakan kedua jenis tersebut diedarkan sesuai dengan kemampuan keuangan pelaku. Upaya pencegahan dan penanggulangan narkotika dapat dilakukan melalui perbaikan dan pengawasan yang ketat terhadap lingkungan yang ada dimasyarakat serta edukasi dan sosialisasi akan ancaman yang berlaku didalam UU No. 35 Tahun 2009.

Kata Kunci: Narapidana; Narkotika; Rekam Jejak

\section{PENDAHULUAN}

Narkotika disatusisimerupakanobatataubahanyangbermanfaat dibidangpengobatan atau pelayanan kesehatan dan pengembangan ilmu pengetahuan dan di sisi lain dapat pula menimbulkan ketergantungan yang sangat merugikan apabila disalahgunakan atau digunakan tanpa pengendalian dan pengawasan yang ketat dan saksama ${ }^{1}$ Salah satu fenomena yang sedang terjadi saat ini adalah penyalahgunaan Narkotika, pada awalnya narkotika hanya digunakan sebagai alat bagi ritual keagamaan dan disamping itu juga dipergunakan untuk pengobatan, adapun jenis narkotika pertama yang digunakan pada mulanya adalah candu atau lazim disebut sebagai madat atau opium. ${ }^{2}$ Hukum positif di indonesia mengatur berkaitan dengan ketersediaan Narkotika untuk kepentingan pelayanan kesehatan dan/atau pengembangan ilmu pengetahuan dan teknologi namun disisi lain juga mengatur berkaitan dengan pemberantasan peredaran gelap narkotika dan prekusor narkotika sehingga Undang-Undang Narkotika merupakan jenis peraturan administrasi yang didalam nya memuat ketentuan pidana.

Bahaya narkotika dari tahun ke tahun menunjukkan peningkatan yang serius dan semakin mengkhawatirkan ${ }^{3}$. Kriminalisasi pengguna narkoba di Asia dan tempat lain di seluruh dunia telah gagal untuk mencegah penggunaan narkoba dan gagal memunculkan efek penghindaran; tidak ada bukti bahwa peningkatan keganasan penegak hukum atau beratnya hukuman mengarah pada keberhasilan pengurangan prevalensi penggunaan narkoba ${ }^{4}$. Banyaknya faktor yang mempengaruhi tingkatan dan pola produksi, penyediaan, dan penggunaan Napza menunjukkan bahwa pemerintah harus mengambil pendekatan yang sangat terstruktur untuk membangun respon kebijakan Napza yang komprehensif dan terintegrasi, perundang-undangan terkait

\footnotetext{
${ }^{1}$ Ketentuan Menimbang Undang-Undang Republik Indonesia Nomor 35 Tahun 2009 Tentang Narkotika

${ }^{2}$ Kusno Adi, 2009, Diversi Sebagai Upaya Alternative Penanggulangan Tindak Pidana Narkotika Oleh Anak, UMM Press, Malang, 2009, hlm 3.

${ }^{3}$ Bachtiar Marpaung, Indonesia in Circle Dark Distribution International Narcotics, IOSR Journal Of Humanities And Social Science IOSR-JHSS, Volume 20, Issue 4, Ver. V, April. 2015, hlm. 42-46.

${ }^{4}$ International Drug Policy Consorcium, Sebuah Pendekatan Kesehatan Masyarakat Terhadap Penggunaan Narkoba Di Asia: Prinsip-prinsip dan praktik-praktik dekriminalisasi, hlm. 12.
} 
Napza dan proses penegakan hukumnya hanya satu dari sekian banyak aktivitas pemerintah yang dapat digunakan untuk mengatasi permasalahan Napza ${ }^{5}$.

Sebagai daerah yang berbatasan langsung dengan negara-negara tetangga, narapidana narkotika yang berada di lapas narkotika Kota Tanjungpinang ${ }^{6}$ mengalami peningkatan pada 2 tahun terakhir sebagaimana tabel berikut:

Tabel 1. Jumlah Narapidana Di Lapas Narkotika Tanjungpinang

\begin{tabular}{|c|c|c|c|c|c|c|c|c|c|}
\hline \multirow[b]{2}{*}{ Tahun } & \multicolumn{6}{|c|}{ Narapidana } & \multirow[b]{2}{*}{ Total } & \multirow[b]{2}{*}{$\begin{array}{c}\text { Kapa } \\
\text { sitas }\end{array}$} & \multirow{2}{*}{$\begin{array}{c}\% \\
\text { Over } \\
\text { Kapa } \\
\text { sitas }\end{array}$} \\
\hline & $\begin{array}{c}\text { Dewasa } \\
\text { Laki- } \\
\text { laki }\end{array}$ & $\begin{array}{l}\text { Dewasa } \\
\text { Peremp }\end{array}$ & $\begin{array}{c}\text { Total } \\
\text { Dewasa }\end{array}$ & $\begin{array}{c}\text { Anak } \\
\text { Laki- } \\
\text { laki }\end{array}$ & $\begin{array}{c}\text { Anak } \\
\text { Peremp }\end{array}$ & $\begin{array}{c}\text { Total } \\
\text { Anak }\end{array}$ & & & \\
\hline $\begin{array}{c}\text { Des } \\
2019\end{array}$ & 864 & 0 & 864 & 0 & 0 & 0 & 864 & 620 & $39 \%$ \\
\hline $\begin{array}{c}\text { Des } \\
2018\end{array}$ & 699 & 0 & 699 & 0 & 0 & 0 & 699 & 620 & $13 \%$ \\
\hline $\begin{array}{c}\text { Des } \\
2017\end{array}$ & 499 & 0 & 499 & 0 & 0 & 0 & 499 & 620 & $0 \%$ \\
\hline $\begin{array}{c}\text { Des } \\
2016\end{array}$ & 238 & 0 & 238 & 0 & 0 & 0 & 238 & 620 & $0 \%$ \\
\hline
\end{tabular}

Sumber: Lapas Narkotika Tanjungpinang Tahun 2019

Dari data di atas, diketahui terdapat peningkatan narapidana pada tahun 2018 dan 2019 dengan over kapasitas $13 \%$ dan $39 \%$. Untuk itu, peneliti tertarik melakukan penelitian yang fokus untuk melihat rekam jejak narapidana sebelum masuk ke lapas narkotika Tanjungpinang. Ketertarikan peneliti dengan fokus diatas dikarenakan masih sedikit penelitian yang melihat kehidupan narapidana sebelum narapidana berada di lapas.

Beberapa penelitian serupa pernah dilakukan antara lain berkaitan dengan tindak pidana narkotika sebagai transnational organized crime ${ }^{7}$, upaya Indonesia secara global menghadapi penyalahgunaan narkotika ${ }^{8}$, pencegahan dan penanggulangan narkoba yang dilakukan oleh BNN daerah ${ }^{9}$, bentuk kebijakan perlindungan terhadap anak dalam pelaksanaan tindak pidana narkotika ${ }^{10}$, upaya pelajar/mahasiswa dalam

\footnotetext{
${ }^{5}$ Konsorsium Internasional Kebijakan Napza, Panduan Kebijakan Narkotika, Psikotropika dan Zat Adiktif Lainnya (Napza), 2012, hlm. 4. http://fileserver.idpc.net/library/IDPC-Drug-Policy-Guide Indonesia-Bahasa.pdf, diakses pada tanggal 20 Juli 2020.

${ }^{6}$ Lembaga Pemasyarakatan Khusus Narkotika Klas II A Tanjungpinang terbentuk berdasarkan Surat Keputusan Menteri Hukum dan HAM RI Nomor : M.04-PR.07.03 Tahun 2007, tanggal 23 Februari 2007 tentang Pembentukan Lembaga Pemasyarakatan Narkotika Yogyakarta dan Tanjungpinang.

${ }^{7}$ Roni Gunawan Raja Gukguk dan Nyoman Serikat Putra Jaya, Tindak Pidana Narkotika Sebagai Transnational Organized Crime, Jurnal Pembangunan Hukum Indonesia, Volume 1, Nomor 3, Tahun 2019, hlm. 337-351.

${ }^{8}$ V.L. Sinta Herindrasti, Drug-free ASEAN 2025: Tantangan Indonesia dalam Penanggulangan Penyalahgunaan Narkoba, Jurnal Hubungan Internasional, Vol. 7, No. 1 / April - September 2018, hlm. 19-33.

${ }_{9}^{9}$ Isnayati Novita dkk, Pencegahan dan Penanggulangan Narkoba Oleh Badan Narkotika Nasional Kota Samarinda, Journal Administrasi Negara, Volume 6 , Nomor 4, 2018, hlm. 8170-8184.

${ }^{10}$ Dery Ulum, Perlindungan Anak dalam Kebijakan Narkotika: Tindak Pidana Narkotika yang Dilakukan Anak, Jurnal Peradilan Indonesia, Vol. 5, Agustus 2016 - Januari 2017, hlm. 87-106.
} 
memperoleh narkotika dilihat dari aspek hukum ${ }^{11}$, kedudukan pengguna narkotika menurut perundang-undangan ${ }^{12}$, penyalahgunaan narkotika dilihat dari aspek Hak Asasi Manusia ${ }^{13}$, rehabilitasi bagi pengguna narkotika ${ }^{14}$, sampai dengan bagaimana kendala dan hambatan yang dihadapi oleh penyidik Polri ${ }^{15}$.

Tujuan dilakukannya penelitian ini adalah untuk mengetahui rekam jejak narapidana kasus narkotika di lembaga pemasyarakatan narkotika Kota Tanjungpinang sebelum narapidana menjalani hukuman. Penelitian ini diharapkan dapat berkontribusi pada penyusunan kebijakan terkait dengan penanggulangan narkotika khususnya aspek pencegahan dengan melihat perilaku pengguna narkotika.

Jenis penelitian yang digunakan adalah survey yang melibatkan 258 responden dari 864 narapidana yang ada di lapas narkotika Kota Tanjungpinang. Pendekatan penelitian yang digunakan melalui sosiological approach dan statute approach. Sumber data yang digunakan adalah data primer dengan menggunakan kuisioner sebagai alat pengumpulan data. Data sekunder yang digunakan berupa literatur-literatur dan peraturan perundang-undangan.

\section{PEMBAHASAN}

Penyalahgunaan Narkotika dan Psikotropika tidak hanya sebagai bahaya laten, tetapi sudah bencana bangsa ini jika terus dibiarkan. Diperkirakan 80 persen pemakai barang haram itu siswa dan mahasiswa yang merupakan generasi bangsa. ${ }^{16}$ Jika terus dibiarkan, bangsa ini dalam waktu 10 tahun ke depan akan kehilangan putri-putri terbaiknya, ancaman Lost Generation akibat Penyalahgunaan Narkotika dan Psikotropika di depan mata. Saat ini terjadi kecenderungan penciptaan The Lost Generation dari generasi muda Indonesia melalui upaya pembusukan bangsa lewat jalur Narkotika dan Psikotropika serta obat-obatan berbahaya (Narkoba) ${ }^{17}$. Sehingga sampai saat kini perang melawan narkotika selalu di gaung-gaungkan oleh pemerintah karena sejatinya jika anak bangsa banyak yang terjerumus dalam lingkaran penyalahgunaan narkotika ini bukan saja merugikan diri pemakai saja namun akan berdampak luas akan merugikan masyarakat bahkan juga negara. Kecendrungan penyalahgunaan narkotika ini juga akan memicu terjadinya kejahatan-kejahatan lain karena kecanduan narkotika atau efek kurangnya

\footnotetext{
${ }^{11}$ Novita Sari, Tinjauan Yuridis Terhadap Upaya Pelajar/Mahasiswa Dalam Memperoleh Narkoba (Studi pada Survei Penyalahgunaan Narkoba di Kelompok Pelajar dan Mahasiswa Tahun 2016), Jurnal Penelitian Hukum De Jure, Vol. 19 No. 1, Maret 2019, hlm. 121-136.

${ }^{12}$ Harris Y. P. Sibuea, Kedudukan Pengguna Narkotika dan Kesiapan Fasilitas Rehabilitasi Bagi Penyalahguna Narkotika Berdasarkan Undang-Undang Nomor 35 Tahun 2009 Tentang Narkotika, Jurnal Negara Hukum, Vol. 6, No. 1, Juni 2015, hlm. 45-63.

${ }^{13}$ Mohammad Indra Bangsawan, Penyalahgunaan Narkoba Sebagai Kejahatan Terhadap Hak Asasi Manusia yang Berdampak Terhadap Keberlangsungan Hidup Manusia, Jurnal Jurisprudence, Vol. 6 No. 2 September 2016, hlm. 8999.

${ }^{14}$ R. A. Alfajriyah F Z dkk, Pelaksanaan Rehabilitasi Sebagai Upaya Penanggulangan Tindak Pidana Narkotika (Studi Pada Loka Rehabilitasi Kalianda), Jurnal POENALE, Vol. 5 No. 6 Tahun 2017, hlm. 23.

${ }^{15}$ Iqbal Taufik, Kendala Dalam Pelaksanaan Pembelian Terselubung (Undercover Buy) Dalam Mengungkap Tindak Pidana Narkotika Oleh Penyidik Polri, Jurnal SASI, Volume 23 Nomor 2, Juli - Desember 2017), hlm. 118-128.

${ }^{16}$ Heriadi Willy, Berantas Narkoba Tak Cukup Hanya Bicara (Tanggung Jawab \& Opini), Penerbit Kedaulatan Rakyat, Yogyakarta, 2005, hlm. 188.

${ }^{17}$ Ibid., hlm. 190.
} 
kesadaran diri akan membuat penggunakan melakukan tindakan-tindakan yang kadang diluar dari batas normal pemikiran manusia.

Undang-Undang Nomor 35 Tahun 2009 Tentang Narkotika merupakan salah satu produk kebijakan hukum pidana bidang administrasi yang mana untuk menjadi acuan dalam mengatur ketersediaan Narkotika untuk kepentingan pelayanan kesehatan dan/atau pengembangan ilmu pengetahuan dan teknologi dan sebagai penyelesaian jika terjadi penyalahgunaan narkotika dalam bentuk pemidanaan. Sebagaimana dikemukakan Koeswadji bahwa tujuan pokok dari pemidanaan adalah sebagai berikut yaitu : ${ }^{18}$

1) Untukmempertahankanketertibanmasyarakat (dehandhavingvandemaatschappelijke orde);

2) Untuk memperbaiki kerugian yang diderita oleh masyarakat sebagai akibat dari terjadinya kejahatan. (het herstel van het doer de misdaad onstane maatschappelijke nadeel);

3) Untuk memperbaiki si penjahat (verbetering vande dader);

4) Untuk membinasakan si penjahat (onschadelijk maken van de misdadiger);

5) Untuk mencegah kejahatan (tervoorkonning van de misdaad)

Pemidanaan terhadap penyalahgunaan narkotika dalam Undang-Undang Nomor 35 Tahun 2009 jika merujuk pada pendapat Koeswadji maka dari lima poin tersebut yang menjadi bagian yang utama adalah bagaimana memperbaiki si penjahat atau narapidana agar dibina dan tidak mengulangi lagi perbuatan kejahatan tersebut. Temuan lapangan yang peneliti peroleh terkait dengan usia narapidana ketika pertama kali tertangkap dengan kasus narkotika sangat bervariasi. usia rentan tertangkap narkotika adalah antara 16 - 40 tahun.

Tabel 2. Usia Ketika Tertangkap Pertama Kali Karena Kasus Narkotika

\begin{tabular}{lccc}
\hline No & Usia & $\begin{array}{c}\text { Usia Pertama Kali } \\
\text { Menggunakan } \\
\text { Narkotika }\end{array}$ & $\begin{array}{c}\text { Usia Pertama Ketika } \\
\text { Tertangkap }\end{array}$ \\
\hline 1. & $\leq 15$ & 8 & 0 \\
\hline 2. & $16-20$ & 36 & 12 \\
\hline 3. & $21-30$ & 157 & 125 \\
\hline 4. & $31-40$ & 38 & 105 \\
\hline 5. & $41-50$ & 11 & 11 \\
\hline 6. & $>50$ & 8 & 258 \\
\hline
\end{tabular}

Sumber: Lapas Narkotika Tanjungpinang Tahun 2019

${ }^{18}$ Koeswadji, 1995, Perkembangan Macam-macam Pidana Dalam Rangka Pembangunan Hukum Pidana, Cetakan I, Citra Aditya Bhakti, Bandung, hlm.12. 
Data di atas menunjukkan pemuda ${ }^{19}$ lebih banyak tertangkap saat mengkonsumsi narkotika. Usia ini memang rentan terhadap pengaruh dan penyalahgunaan narkotika yang termasuk dalam kenakalan khusus bagi remaja atau pemuda ${ }^{20}$. Penyimpangan sosial yang dilakukan oleh para remaja atau individu terhadap penyalahgunaan narkoba akan mengakibatkan masalah sosial, kejadian tersebut terjadi karena adanya interaksi sosial antar individu, individu dengan kelompok, dan antar kelompok. ${ }^{21}$ Penyalahgunaan narkoba dikalangan remaja merupakan tindakan yang tidak sesuai dengan norma dan nilai sosial yang berlaku dalam masyarakat dinamakan perilaku menyimpang. Penyimpangan terjadi apabila seseorang atau sekelompok orang tidak mematuhi norma atau patokan dan nilai yang sudah baku di masyarakat. ${ }^{22}$ Penyimpangan tersebut dikategorikan kejahatan.

Hermann Mannheim mengungkapkan, bahwa terdapat 3 (tiga) pendekatan yang dapat dilakukan dalam mempelajari masalah kejahatan, yaitu salah satu dari pendekatan tersebut adalah pendekatan Deskriptif. Yang dimaksud dengan pendekatan deskriptif adalah suatu pendekatan dengan cara melakukan obserfasi dan pengumpulan data yang berkaitan dengan fakta-fakta tentang kejahatan dan pelaku kejahatan seperti:

a) Bentuk tingkah laku criminal,

b) Bagaimana kejahatan dilakukan,

c) Frekuensi kejahatan pada waktu dan tempat yang berbeda,

d) Ciri-ciri khas pelaku kejahatan, seperti usia, jenis kelamin dan sebagainya,

e) Perkembangan karir seorang pelaku kejahatan. ${ }^{23}$

Pemuda atau remaja merupakan usia yang rentan, tidak dipungkiri jika disandingkan dengan pendapat Hermann Mannheim pada poin (d) maka dapat disimpulkan bahwa usia dan fakta sebab terjadi kejahatan memiliki hubungan yang sangat erat. Usia yang muda secara psikologis masih dalam proses dimana masih tingginya keingintahuan dan mudah terpengaruh terhadap lingkungan. Meskipun pendapat Hermann Mannheim masih dalam bentuk yang sederhana namun jika kita mengamati tabel diatas akan terlihat bahwa usia narapidana pertama kali menggunakan narkotika menunjukkan usia yang masih muda yang paling tinggi yaitu usia rentan di umur 21-30 tahun. Usia yang makin tinggi memiliki kematangan secara Psikologis sehingga sudah dapat memikirkan secara matang apa yang di perbuat nya. Tabel tersebut menggambarkan usia 40-50 tahun dan atas 50 tahun menunjukkan angka yang fluktuatif sangat rendah dibandingkan dengan

\footnotetext{
${ }^{19}$ Menurut Pasal 1 angka 1 Undang-Undang Nomor 40 Tahun 2009 tentang Kepemudaan, pemuda adalah warga Negara Indonesia yang memasuki periode penting pertumbuhan dan perkembangan yang berusia 16 (enam belas) sampai 30 (tiga puluh) tahun.

${ }^{20}$ Maudy Pritha Amanda, dkk, Penyalahgunaan Narkoba Di Kalangan Remaja (Adolescent Substance Abuse), Jurnal Penelitian dan PPM UNPAD, Vol 4, No. 2, Juli 2017, hlm. 342.

${ }^{21}$ Soekanto, Soejono, 2009, Sosiologi Suatu Pengantar, PT. Raja Grafindo Persada, Jakarta, hlm. 312.

${ }^{22}$ Dina Novitasari, Rehabilitasi Terhadap Terhadap Anak Korban Penyalahgunaan Narkoba, Jurnal Hukum Khaira Ummah Vol. 12. No. 4 Desember 2017, hlm. 920

${ }^{23}$ Simanjuntak B, 1984, Pengantar Kriminologi dan Patologi Sosial, Tarsito, Bandung, hlm. 79.
} 
rentan usia lainnya. Namun selanjutnya Hermann Mannheim menegaskan adanya beberapa syarat yang harus dipenuhi bila menggunakan pendekatan deskriptif, yaitu: ${ }^{24}$

a) Pengumpulan fakta tidak dapat dilakukan secara random.oleh karena itu fakta-fakta yang diperoleh harus dilakukan secara selektif.

b) Herusdilakukanpenafsiran,evaluasidanmemberikanpengertiansecaraumumterhadap fakta-faktayangdiperoleh.tanpadilakukanpenafsiran,evaluasidanmemberipengertian secara umum,maka fakta-fakta tersebut tidak akan mempunyai arti

Masa remaja merupakan masa transisi, yaitu suatu fase perkembangan antara masa anak-anak dan masa dewasa. Masalah utama remaja pada umumnya adalah pencarian jati diri. Mereka mengalami krisis identitas karena untuk dikelompokkan ke dalam kelompok anak-anak merasa sudah besar, namun kurang besar untuk dikelompokkan dalam kelompok dewasa. Hal ini merupakan masalah bagi setiap remaja. Oleh karena itu, seringkali memiliki dorongan untuk menampilkan dirinya sebagai kelompok tersendiri. Dorongan ini disebut sebagai dorongan originalitas. Namun dorongan ini justru seringkali menjerumuskan remaja pada masalah-masalah yang serius, seperti narkoba. ${ }^{25}$ Hal tersebut sejalan dengan hasil penelitian yang dilakukan oleh BNN yang menyebutkan pada tahun 2019 terjadi peningkatan penyalahgunaan narkotika dikalangan remaja sebesar $24 \%-28 \%{ }^{26}$.

Tabel 3. Pasal Yang Dikenakan (Berdasarkan Putusan)

\begin{tabular}{lcc}
\hline No & Pasal & Responden \\
\hline 1. & Pasal 111 UU No. 35 Tahun 2009 Tentang Narkotika & 15 \\
\hline 2. & Pasal 112 UU No. 35 Tahun 2009 Tentang Narkotika & 128 \\
\hline 3. & Pasal 113 UU No. 35 Tahun 2009 Tentang Narkotika & 2 \\
\hline 4. & Pasal 114 UU No. 35 Tahun 2009 Tentang Narkotika & 75 \\
\hline 5. & Pasal 115 UU No. 35 Tahun 2009 Tentang Narkotika & 2 \\
\hline 6. & Pasal 127 UU No. 35 Tahun 2009 Tentang Narkotika & 36 \\
\hline 7. & Pasal 129 UU No. 35 Tahun 2009 Tentang Narkotika & 0 \\
\hline & Jumlah & 258 \\
\hline
\end{tabular}

Sumber: Lapas Narkotika Tanjungpinang Tahun 2019

Berdasarkan data di atas, sebagian besar narapidana merupakan orang yang memiliki, menyimpan, menguasai, atau menyediakan Narkotika Golongan I bukan

\footnotetext{
${ }^{24}$ Ibid.

${ }^{25}$ Maudy Pritha Amanda, dkk, Penyalahgunaan.. Loc., Cit.

${ }^{26}$ Badan Narkotika Nasional Republik Indonesia, Penggunaan Narkotika dikalangan Remana Meningkat, https:// bnn.go.id/penggunaan-narkotika-kalangan-remaja-meningkat/, diakses pada tanggal 24 Agustus 2020.
} 
tanaman dan orang yang tanpa hak atau melawan hukum menawarkan untuk dijual, menjual, membeli, menerima, menjadi perantara dalam jual beli, menukar, atau menyerahkan Narkotika Golongan ${ }^{27}$. Tingkatan penyalahgunaan biasanya sebagai berikut: ${ }^{28}$

1) Coba-coba, berawal dari mencoba sesuatu yang baru serta belum diketahui penyebab dan akibat dari benda baru, asal benda baru itu sudah dicoba merasa hidup lebih maju dan modern (mengikuti pekembangan jaman).

2) Senang-senang, setelah mencoba benda itu merasa lebih kini dan merasakan senangsenang yang sesaat karena efek penyalahgunaan tersebut, merasa senang dan semua orang ingin merasakan kesenangan setiap waktu dari itu terus dan lagi memakainya tanpa mengetahui dampak buruk dari hal tersebut.

3) Menggunakan pada saatataukeadaan tertentu, dalam keadaan tertentu seperti depresi, stres, galau ingin menghilangkan rasa itu kemudian menyalahgunakan narkoba agar rasa hilang dan kembali merasa senang.

4) Penyalahgunaan, merasalebih baik memakaibarang tersebut, lagi danlagimemakainya padahal kegiatan tersebut buruk dampaknya karena itu penyalahgunaan narkoba.

5) Ketergantungan, narkoba membuat ketergantungan terhadap seseorang yang memakainya karena pecandu sudah terbiasa memakainya dan merasa lebih tenang membuat pencandu tersebut ketergantungan terhadap penyalahgunaan narkoba.

Umumnya para kriminolog mengatakan bahwa penyebab seseorang melakukan kejahatan di pengaruhi oleh faktor internal yaitu faktor yang bersumber dari dalam diri seseorang (fenomenal) dan faktor eksternal yaitu faktor yang bersumber dari luar diri seseorang (struktur-struktur sosial). Kedua faktor ini saling berkaitan satu sama lain dan tentunya tidak berdiri sendiri, penyebabnya dapat dipengaruhi oleh berbagai macam kondisi yang mendukung. ${ }^{29}$ Manusia yang demikian berpendirian bahwa halhal tersebut dapat dilakukan melalui penyalahgunaan narkotika, bahwa narkotika bisa memiliki daya tersebut juga didengarnya melalui teman-temannya. Lingkungan pergaulan khusus pada pecandu narkotika senantiasa ada karena pengedar narkotika gelap dengan sindikatnya senantiasa mencari korban. Maka ditengah lingkungan pergaulan di mana pelaku dengan aneka kondisi indentitas berada di dalamnya terjadi penawaran dan permintaan (suplay and demand) yang sukar dihentikan. ${ }^{30}$ Berdasarkan data yang diperoleh dari Lapas Narkotika Tanjungpinang Tahun 2019 berkaitan dengan alasan utama menggunakan Narkotika yaitu dapat digambarkan dalam tabel berikut ini:

\footnotetext{
${ }^{27}$ Lihat Undang-Undang Nomor 35 Tahun 2009 Tentang Narkotika.

28 Megahartati, Tingkatan Penyalahgunaan Narkoba, https://dedihumas.bnn.go.id/read/section/artikel/2012/08/27/526/tingkatan-penyalahgunaan-narkoba, diakses pada tanggal 24 Agustus 2020

${ }^{29}$ Yesmil Anwar dan Adang, 2013, Kriminologi, Refika Aditama, Bandung, hlm. 57.

${ }^{30}$ Andi Helmi Adam, Tinjauan Kriminologi Kejahatan Narkotika Yang Dilakukan Oleh Anak, Jurnal Al Hikam, Vol 1 No 1,2017, hlm. 73.
} 
Tabel 4. Alasan Utama Menggunakan Narkotika

\begin{tabular}{clc}
\hline No & \multicolumn{1}{c}{ Alasan } & Responden \\
\hline 1. & Karena ingin tahu & 85 \\
\hline 2. & Orang tua / keluarga tidak perhatian & 2 \\
\hline 3. & Lingkungan yang memungkinkan & 45 \\
\hline 4. & Ajakan kawan & 62 \\
\hline 5. & Menghilangan stress & 25 \\
\hline 6. & Agar diterima oleh kawan & 3 \\
\hline 7. & Lainnya ... & Jumlah \\
\hline
\end{tabular}

Sumber: Lapas Narkotika Tanjungpinang Tahun 2019

Dari tabel diatas diketahui bahwa terdapat 3 alasan utama narapidana yang berada dilapas narkotika Tanjungpinang mengkonsumsi narkotika yakni rasa ingin tahu, ajakan kawan dan faktor lingkungan sekitar narapidana dulunya. Berdasarkan pendapat Edwin H. Sutherland dalam Teori Asosiasi Deferensial yang dikemas dalam dua versi, Pertama Pengertian asosiasi diferensial, oleh Sutherland dimaksudkan bahwa, tidak berarti bahwa hanya kelompok pergaulan dengan penjahat akan menyebabkan perilaku criminal, tetapi yang terpenting adalah isi dari proses komunikasi dengan orang lain. ${ }^{31}$

Munculnya teori asosiasi diferensial ini didasarkan pada tiga hal, yaitu: ${ }^{32}$

1) Setiap orang akan menerima dan mengikuti pola-pola perilaku yang dapat dilaksanakan

2) Kegagalan untuk mengikuti pola tingkah laku menimbulkan inkonsistensi dan ketidakharmonisan.

3) Konflik budaya (Conflick of Cultures )merupakan prinsip dasar dalam menjelaskan kejahatan.

Versi kedua, yang disajikan pada bukunya edisi ke empat (1947), Sutherland menekankan bahwa semua tingkah laku dipelajari. Dengan kata lain, pola perilaku jahat tidak diwariskan tetapi dipelajari melalui suatu pergaulan yang akrab. ${ }^{33}$ Dalam kedua versi tersebut jika disandingkan dengan tabel diatas dapat dimaknai bahwa faktor lingkungan atau ajakan kawan memang bukan menjadi faktor yang muntlak sebagai pemicu namun satu sisi harus dipahami bahwa lingkungan memiliki resiko yang sangat berpengaruh terhadap segala tindakan itu. Melihat alasan penggunaakan narkoba diatas juga rasa keingin tahuan memiliki nilai yang lebih tinggi dari alasan lainnya sehingga semua tingkah laku tersebut karena keingintahuan dipelajari dan bukan dari warisan. Hal serupa juga terlihat dari hasil penelitian yang dilakukan oleh Catur Mei Wulandari

\footnotetext{
${ }^{31}$ Made Derma Weda, 1996, Krimonologi, Raja Grafindo Persada, Jakarta, hlm. 29

${ }^{32}$ Ibid.

${ }^{33}$ Ibid.
} 
$\mathrm{dkk}^{34}$ yang menemukan bahwa faktor mudah terpengaruh dan mencoba hal baru menjadi faktor yang dominan pada narapidana di lapas kelas IIA Kabupaten Jember.

Ketergantungan Narkotika adalah kondisi yang ditandai oleh dorongan untuk menggunakan Narkotika secara terus-menerus dengan takaran yang meningkat agar menghasilkan efek yang sama dan apabila penggunaannya dikurangi dan/atau dihentikan secara tiba-tiba, menimbulkan gejala fisik dan psikis yang khas". ${ }^{35}$ dorongan tersebut akan menyebabkan penggunaan narkotika sulit untuk sekali dan akan ada pemakaian selanjutnya atau menjadi rutinitas. berikut data berkaitan dengan intensitas penggunaan narkotika yang dapat digambarkan dalam tabel di bawah ini:

Tabel 5. Intensitas Menggunakan Narkotika

\begin{tabular}{|c|c|c|}
\hline No & Waktu & Responden \\
\hline 1. & Setiap hari & 47 \\
\hline 2. & Seminggu sekali- dua kali & 55 \\
\hline 3. & Sebulan sekali & 18 \\
\hline \multirow[t]{2}{*}{4.} & Tidak tentu & 138 \\
\hline & Jumlah & 258 \\
\hline
\end{tabular}

Sumber: Lapas Narkotika Tanjungpinang Tahun 2019

Berdasarkan tabel tersebut dapat diketahui bahwa hampir semua narapidana yang dijadikan responden didalam penelitian ini memiliki ketergantungan terhadap narkotika dimana intensitas penggunaan narkotika oleh narapidana hampir menjadi aktivitas rutin yang dilakukan. Meskipun intensitas tidak tertentu memiliki nilai yang lebih tinggi namun dirasakan bahwa kecanduan terhadap narkotika akan membuat ketergantungan dan akan berulang-ulang dalam pemakaiannya.

Pecandu pada dasarnya adalah merupakan korban penyalahgunaan tindak pidana narkotika yang melanggar peraturan pemerintah, dan mereka itu semua merupakan warga negara Indonesia yang diharapkan dapat membangun negeri ini dari keterpurukan hampir di segala bidang. ${ }^{36}$ Sementara itu, terkait tindak pidana narkotika, secara umum dapat dikualifikasikan menjadi beberapa bentuk tindak pidana. Namun, yang sering terjadi di masyarakat adalah berhubungan dengan pemakai dan pengedar narkotika. Jika berbicara tentang pengedar narkotika, sudah jelas kiranya telah terjadi interaksi antara pengedar dan pembeli narkotika, keduanya merupakan pelaku tindak pidana narkotika. Akan tetapi, jika kita berbicara tentang pemakai narkotika, sejauh ini

\footnotetext{
${ }^{34}$ Catur Mei Wulandari dkk, Faktor-Faktor yang Mempengaruhi Penyalahgunaan NAPZA Pada Masyarakat di Kabupaten Jember, Jurnal Farmasi Komunitas Vol. 2, No. 1, 2015, hlm. 3.

${ }_{35}$ Pasal 1 angka 14 Undang-Undang Republik Indonesia Nomor 35 Tahun 2009 Tentang Narkotika

${ }^{36}$ Moh. Taufik Makarao, Suhasril, dan Moh. Zakky A.S, 2003, Tindak Pidana Narkotika, Ghalia Indonesia, Jakarta, 2003, hlm. 74-75.
} 
masih terdapat perbedaan sudut pandang mengenai pemakai narkotika. Hukum positif menyatakan, pemakai narkotika adalah pelaku tindak pidana karena telah memenuhi kualifikasi dalam Undang-Undang Narkotika.Tindak pidananarkotika seperti penyalahgunaan narkotika dalam kajian kriminologi dapat digolongkan sebagai kejahatan tanpa korban atau victimless crime. Penggolangan ini merujuk kepada sifat kejahatan tersebut yaitu adanya dua pihak yang melakukan transaksi atau hubungan (yang dilarang)namun keduanya merasa tidak menderita kerugian atas pihak lain. ${ }^{37}$

Dalam hal tertentu, seorang yang hanya menggunakan narkoba bukan pengedar ataupun bandar berada dalam persimpangan peran, sebagai pelaku atau sebagai korban. Di Indonesia, seorang terdakwa tindak pidana penyalahgunaan narkotika hanya dapat memperoleh tindakan hukum berupa rehabilitasi bila telah memenuhi persyarataan dalam Surat Edaran Mahkamah Agung Nomor: 04/Tahun 2010 yaitu: terdakwa dalam kondisi tertangkap tangan, pada saat tertangkap tangan barang bukti untuk ganja 5 gram, surat ijin laboratorium positif menggunakan narkotika, surat keterangan dari dokter jiwa/psikiater pemerintah, tidak terdapat bukti bahwa yang bersangkutan terlibat peredaran Narkotika dan adanya keterangan ahli yang menerangkan seberapa besar kondisi/taraf kecanduan dari terdakwa. ${ }^{38}$ Berdasarkan tipologi korban penyalahgunaan narkotika yang diidentifikasi menurut keadaan dan status korban adalah sebagai berikut:

1. Unrelated victims, yaitu korban yang tidak ada hubungannya sama sekali dengan pelaku

2. Provocativevictims, yaituseseorangyangsecaraaktifmendorongdirinyamenjadikorban

3. Participating victims, yaitu seseorang yang tidak berbuat, akan tetapi dengan sikapnya justru mendorong dirinya menjadi korban

4. Biologically weak victims, yaitu mereka yang secara fisik memiliki kelemahan yang menyebabkan ia menjadi korban

5. Socially weak victims, yaitu mereka yang memiliki kedudukan sosial yang lemah yang menyebabkan ia menjadi korban

6. Self victimizing victims, yaitu mereka yang menjadi korban karena kejahatan yang dilakukannya sendiri

Dari tipologi korban penyalahgunaan narkotika di atas, pecandu narkotika merupakan "self victimizing victims", karena pecandu narkotika menderita sindroma ketergantungan akibat dari penyalahgunaan narkotika yang dilakukannya sendiri. ${ }^{39}$ Dalam penggunaan narkotika selalu dibarengi dengan beberapa aktivitas lainnya yang dapat digambarkan dalam tabel berikut:

Tabel 6. Aktivitas Lain Selain Menggunakan Narkotika

\footnotetext{
${ }^{37}$ Muhammad Faisal Kamaruddin, Abdul Agis, Ahmad Fadil, Penegakan Hukum Terhadap Penyalahgunaan Narkotika Studi Kota Makassar, Journal of Lex Philosophy (JLP), Vol.1, No. 1, Juni 2020, hlm.62.

${ }^{38}$ Dian Herdian Silalahi, Penanggulangan Tindak Pidana Penyalahgunaan Narkotika di SATRES Narkoba Polres Tebing Tinggi, Jurnal Ilmiah Penegakan Hukum, Vol. 5 No. 2 Desember 2018, hlm. 62

${ }^{39}$ Dikdik M.Arief Mansur dan Elisatris Gultom, 2007, Urgensi Perlindungan Korban Kejahatan, PT. Raja Grafindo Persada, Jakarta, hlm. 49-50
} 


\begin{tabular}{|c|c|c|}
\hline No & Aktivitas & Responden \\
\hline 1. & Merokok & 152 \\
\hline 2. & Minum-minuman keras & 51 \\
\hline 3. & Seks pra nikah & 33 \\
\hline 4. & Kebut-Kebutan & 5 \\
\hline 5. & Berjudi & 14 \\
\hline 6. & Berkelahi & 0 \\
\hline 7. & Ikut kelompok / geng & 3 \\
\hline & Jumlah & 258 \\
\hline
\end{tabular}

\section{Sumber: Lapas Narkotika Tanjungpinang Tahun 2019}

Berdasarkan temuan dilapas narkotika Tanjungpinang diketahuibahwa sebagian besar narapidana narkotika menghisap rokok dan minum-minuman keras serta melakukan seks pranikah selain dari mengkonsumsi narkotika. Hasil di atas sejalan dengan hasil penelitian Harbia, $\mathrm{dkk}^{40}$ serta penelitian Sri Wahyuni dan Iksan Fahmi ${ }^{41}$. Aktivitas lain selain menggunakan narkotika sesungguhnya akan memicu perbuatan penyimpangan lainnya yang mana akan merugikan baik pelaku maupun akan menimbulkan keresahan didalam masyarakat. Zat yang terkandung dalam narkotika, mempunyai pengaruh besar pada diri manusia, baik secara mental maupun fisik. Seringkali pengaruh tersebut membuat manusia seolah-olah berpindah ke alam lain sehinga dapat melupakan rasa sakit maupun beratnya tekanan hidup. Secara umum sifat khas yang ditimbulkan oleh zat-zat tersebut, adalah: ${ }^{2}$

a) Sebagai stimulan yaitu zat-zat yang menimbulkan efek mengaktifkan kerja susunan saraf pusat pada pemakainya.

b) Sebagai halusinogen yaitu zat yang menimbulkan efek halusinasi atau angan-angan pada pemakainya.

c) Sebagai analgesic yaitu zat yang menimbulkan efek menghilangkan rasa sakit.

Suatu akibat dari keingintahuan, coba-coba atau terpengaruh dengan faktor lainnya maka penggunaan narkotika pertama kali akan menyebabkan keberlanjutan dan akan sulit diakhiri ketergantungan tersebut. Berikut jenis pertama kali narkotika yang dikonsumsi/diedarkan oleh oleh narapidana narkotika:

Tabel 7. Jenis Narkotika Pertama Kali Dikonsumsi/Diedarkan

\footnotetext{
${ }^{40}$ Harbia, Multazam M, Asrina A, Dampak Penyalahgunaan Narkotika, Psikotropika dan Zat Aditif Lainnya (NAPZA) terhadap Perilaku Seks Pranikah. Window of Health : Jurnal Kesehatan, Vol. 1 No. 3 Juli 2018, hlm. 207.

${ }^{41}$ Sri Wahyuni dan Iksan Fahmi, Determinan Perilaku Seksual Pra Nikah Remaja Pria di Indonesia Hasil SDKI, Jurnal Euclid, Vol. 6, No. 2, Juli 2019, hlm. 184.

${ }_{42}$ Asrianto Zainal, Penegakkan Hukum Terhadap Kejahatan Narkotika Ditinjau Dari Aspek Kriminologi , Jurnal Al-'Adl, Vol. 6 No. 2 Juli 2013, hlm. 48.
} 


\begin{tabular}{|c|c|c|}
\hline No & Waktu & Responden \\
\hline 1. & Ganja & $119 \mathrm{~s}$ \\
\hline 2. & Heroin & 0 \\
\hline 3. & Shabu-shabu & 101 \\
\hline 4. & Puthauw & 0 \\
\hline 5. & Morfin & 0 \\
\hline 6. & Ekstasi & 15 \\
\hline 7. & Pil koplo & 14 \\
\hline 8. & Megadon & 0 \\
\hline 9 & Ineks & 9 \\
\hline 10. & Lainnya ... & 0 \\
\hline & Jumlah & 258 \\
\hline
\end{tabular}

Sumber: Lapas Narkotika Tanjungpinang Tahun 2019

Ganja dan sabu-sabu menjadi jenis narkotika yang banyak dikonsumsi pertama kali oleh 220 responden pada lapas narkotika Tanjungpinang. Jika melihat kondisi dilapangan memang kedua jenis narkotika ini sangat mudah diperoleh ditengah-tengah masyarakat. Berdasarkan temuan lapangan diketahui bahwa kedua jenis narkotika ini harganya relatif terjangkau oleh para narapidana. Diketahui juga bahwa kedua jenis narkotika ini mudah diperoleh karena didalam pendistribusiannya dikemas dalam kemasan yang disesuaikan dengan kemampuan responden dulunya sebelum berada dilapas narkotika Tanjungpinang.

Melepaskan ketergantungan dari narkotika merupakan hal yang tidak mudah, sehingga sering terjadi narapidana narkotika yang setelah menyelesaikan masa pidana nya di lembaga pemasyarakatan kembali berulah atau mengulangi lagi tindak pidana yang serupa. Sejatinya pemerintah sudah menyediakan tempat untuk rehabilitasi bagi penyalahgunaan narkotika namun masih banyak ditemui keengganan keluarga dan penyalahgunaan narkotika untuk melakukan rehabilitasi medis. Menurut Kristianingsih narapidana narkotika merupakan bagian dari narapidana dengan kondisi yang berbeda dan spesifik, yaitu mempunyai karakter atau perilaku yang cenderung berbeda akibat penggunaan narkoba yang dikonsumsi mereka selama ini, seperti kurangnya tingkat kesadaran akibat rendahnya kemampuan penyerapan, keterpurukan kesehatan dan sifat over reaktif dan over produktif. Akibatnya narapidana kasus narkotika perlu penanganan khusus daripada narapidana kasus lain selama berada di lapas ataupun rutan. ${ }^{43}$ Bukan saja dorongan dari luar diri narapidana saja namun menghilangkan ketergantungan narkotika tersebut juga harus datang dari dalam diri narapidana tersebut. Melihat

${ }^{43}$ S.A Kristianingsih, "Pemaknaan Pemenjaraan pada Narapidana Narkoba di Rumah Tahanan Salatiga," Humanitas Vol 6, No. 1 2009, hlm. 1-15. 
bagaimana upaya narapidana narkotika untuk keluar dari ketergantungan dapat di lihat dalam tabel berikut ini:

Tabel 8. Upaya untuk Keluar Dari Ketergantungan Narkotika

\begin{tabular}{llc}
\hline No & Waktu & Responden \\
\hline 1. & Tidak pernah & 25 \\
\hline $2 . \quad$ Pernah & & 233 \\
\hline & & 258
\end{tabular}

Sumber: Lapas Narkotika Tanjungpinang Tahun 2019

Sebanyak 90,3 \% narapidana yang berada dilapas Tanjungpinang telah berupaya untuk keluar dari ketergantungan narkotika. Akan tetapi jika merujuk pada tabel 4 diatas, pengaruh ajakan kawan dan lingkungan menjadi penyebab narapidana narkotika dilapas Tanjungpinang sulit untuk keluar dari ketergantungan narkotika. Oleh karena itu berdasarkan wawancara peneliti dengan narapidana sangat dibutuhkan dukungan dari keluarga dan lingkungan yang sehat guna keluar dari ketergantungan narkotika ${ }^{44}$.

\section{SIMPULAN}

Hasil penelitian diketahui bahwa terdapat pengguna mayoritas narapidana narkotika dilapas Tanjungpinang berusia 16-40 tahun ketika pertama kali ditangkap dengan pasal mayoritas yang dikenakan adalah Pasal 112 UU No. 35 Tahun 2009 tentang Narkotika. Rasa ingin tahu, ajakan teman dan faktor lingkungan yang menyebabkan narapidana dilapas narkotika Tanjungpinang terjerumus pada narkotika. Aktivitas lain yang dilakukan oleh responden selain mengkonsumsi narkotika adalah merokok, miras dan melakukan sek pra nikah. Mudahnya memperoleh narkotika jenis ganja dan sabu-sabu dikarenakan kedua jenis tersebut diedarkan sesuai dengan kemampuan keuangan pelaku, 90 \% narapidana sudah berusaha untuk keluar dari ketergantungan narkotika. Dari kondisi diatas, upaya pencegahan dan penanggulangan narkotika dapat dilakukan melalui perbaikan dan pengawasan yang ketat terhadap lingkungan yang ada dimasyarakat serta edukasi dan sosialisasi akan ancaman yang berlaku didalam UU No. 35 Tahun 2009 tentang Narkotika.

\footnotetext{
${ }^{44}$ Hasil wawancara dengan narapidana dilapas narkotika Tanjungpinang pada tanggal 23 Juli 2020.
} 


\section{DAFTAR PUSTAKA}

\section{Buku}

Adi, Kusno, (2009), Diversi Sebagai Upaya Alternative Penanggulangan Tindak Pidana Narkotika Oleh Anak, UMM Press, Malang.

Anwar, Yesmil dan Adang, (2013), Kriminologi, Refika Aditama, Bandung

Derma Weda, Made, (1996), Krimonologi, Raja Grafindo Persada, Jakarta.

Koeswadji, (1995), Perkembangan Macam-macam Pidana Dalam Rangka Pembangunan Hukum Pidana, Cetakan I, Citra Aditya Bhakti, Bandung.

M.Arief, Dikdik Mansur dan Elisatris Gultom, (2007), Urgensi Perlindungan Korban Kejahatan, PT. Raja Grafindo Persada, Jakarta.

Simanjuntak B, (1984), Pengantar Kriminologi dan Patologi Sosial, Tarsito, Bandung.

Soekanto, Soejono, (2009), Sosiologi Suatu Pengantar, PT. Raja Grafindo Persada, Jakarta.

Taufik Makarao, Moh., Suhasril, dan Moh. Zakky A.S, (2003), Tindak Pidana Narkotika, Ghalia Indonesia, Jakarta.

Willy, Heriadi, (2005), Berantas Narkoba Tak Cukup Hanya Bicara (Tanggung Jawab \& Opini), Penerbit Kedaulatan Rakyat, Yogyakarta.

Jurnal dan karya ilmiah lain

AlfajriyahFZ,R.A.dkk,(2017),PelaksanaanRehabilitasi Sebagai UpayaPenanggulangan Tindak Pidana Narkotika (Studi Pada Loka Rehabilitasi Kalianda), Jurnal POENALE, Vol. 5 No. 6.

Faisal Kamaruddin, Muhammad., Abdul Agis, Ahmad Fadil, (2020), Penegakan Hukum Terhadap Penyalahgunaan Narkotika Studi Kota Makassar, Journal of Lex Philosophy (JLP), Vol.1, No. 1.

Gunawan Raja Gukguk, Roni dan Nyoman Serikat Putra Jaya, (2019), Tindak Pidana Narkotika Sebagai Transnational Organized Crime, Jurnal Pembangunan Hukum Indonesia, Vol. 1, No. 3.

Harbia, Multazam M, Asrina A, (2018), Dampak Penyalahgunaan Narkotika, Psikotropika dan Zat Aditif Lainnya (NAPZA) terhadap Perilaku Seks Pranikah. Window of Health : Jurnal Kesehatan, Vol. 1 No. 3.

Herdian Silalahi, Dian, (2018), Penanggulangan Tindak Pidana Penyalahgunaan Narkotika di SATRES Narkoba Polres Tebing Tinggi, Jurnal Ilmiah Penegakan Hukum, Vol. 5 No. 2.

Helmi Adam, Andi, (2017), Tinjauan Kriminologi Kejahatan Narkotika Yang Dilakukan Oleh Anak, Jurnal Al Hikam, Vol 1 No 1.

Indra Bangsawan, Mohammad (2016), Penyalahgunaan Narkoba Sebagai Kejahatan Terhadap Hak Asasi Manusia yang Berdampak Terhadap Keberlangsungan Hidup Manusia, Jurnal Jurisprudence, Vol. 6 No. 2.

International Drug Policy Consorcium, (tt), Sebuah Pendekatan Kesehatan Masyarakat Terhadap Penggunaan Narkoba Di Asia: Prinsip-prinsip dan praktik-praktik 
dekriminalisasi.

Kristianingsih, S.A (2009), Pemaknaan Pemenjaraan pada Narapidana Narkoba di Rumah Tahanan Salatiga, Humanitas Vol 6, No. 12009.

Marpaung, Bachtiar, (2015), Indonesia in Circle Dark Distribution International Narcotics, IOSR Journal Of Humanities And Social Science IOSR-JHSS, Vol, 20, Issue 4.

Mei Wulandari, Catur dkk, (2015), Faktor-Faktor yang Mempengaruhi Penyalahgunaan NAPZA Pada Masyarakat di Kabupaten Jember, Jurnal Farmasi Komunitas Vol. 2, No. 1.

Novita, Isnayati dkk, (2018), Pencegahan dan Penanggulangan Narkoba Oleh Badan Narkotika Nasional Kota Samarinda, Journal Administrasi Negara, Vol. 6, No. 4.

Novitasari, Dina, (2017), Rehabilitasi Terhadap Terhadap Anak Korban Penyalahgunaan Narkoba, Jurnal Hukum Khaira Ummah Vol. 12. No. 4.

Pritha Amanda, Maudy dkk, (2017), Penyalahgunaan Narkoba Di Kalangan Remaja (Adolescent Substance Abuse), Jurnal Penelitian dan PPM UNPAD, Vol 4, No. 2.

Sari, Novita, (2019), Tinjauan Yuridis Terhadap Upaya Pelajar/Mahasiswa Dalam Memperoleh Narkoba (Studi pada Survei Penyalahgunaan Narkoba di Kelompok Pelajar dan Mahasiswa Tahun 2016), Jurnal Penelitian Hukum De Jure, Vol. 19 No. 1.

Sinta Herindrasti, V.L. (2018), Drug-free ASEAN 2025: Tantangan Indonesia dalam Penanggulangan Penyalahgunaan Narkoba, Jurnal Hubungan Internasional, Vol. 7, No. 1.

Taufik, Iqbal, (2017), Kendala Dalam Pelaksanaan Pembelian Terselubung (Undercover Buy) Dalam Mengungkap Tindak Pidana Narkotika Oleh Penyidik Polri, Jurnal SASI, Vol. 23 No. 2.

Ulum, Dery, (2016), Perlindungan Anak dalam Kebijakan Narkotika: Tindak Pidana Narkotika yang Dilakukan Anak, Jurnal Peradilan Indonesia, Vol. 5, No. 2.

Y. P. Sibuea, Harris, (2015), Kedudukan Pengguna Narkotika dan Kesiapan Fasilitas Rehabilitasi Bagi Penyalahguna Narkotika Berdasarkan Undang-Undang Nomor 35 Tahun 2009 Tentang Narkotika, Jurnal Negara Hukum, Vol. 6, No. 1.

Wahyuni, Sri dan Iksan Fahmi, (2019), Determinan Perilaku Seksual Pra Nikah Remaja Pria di Indonesia Hasil SDKI, Jurnal Euclid, Vol. 6, No. 2.

Zainal, Asrianto, (2013), Penegakkan Hukum Terhadap Kejahatan Narkotika Ditinjau Dari Aspek Kriminologi, Jurnal Al-'Adl, Vol. 6, No. 2.

\section{Peraturan Perundang-undangan}

Undang-Undang Republik Indonesia Nomor 35 Tahun 2009 Tentang Narkotika

Undang-Undang Nomor 40 Tahun 2009 tentang Kepemudaan

Surat Keputusan Menteri Hukum dan HAM RI Nomor : M.04-PR.07.03 Tahun 2007, tanggal 23 Februari 2007 tentang Pembentukan Lembaga Pemasyarakatan Narkotika Yogyakarta dan Tanjungpinang. 


\section{Website}

Badan Narkotika Nasional Republik Indonesia, Penggunaan Narkotika dikalangan Remana Meningkat, https://bnn.go.id/penggunaan-narkotika-kalangan-remajameningkat/, diakses pada tanggal 24 Agustus 2020 Pukul 15.00 WIB.

Konsorsium Internasional Kebijakan Napza, Panduan Kebijakan Narkotika, Psikotropika dan Zat Adiktif Lainnya (Napza), 2012, hlm. 4. http://fileserver.idpc.net/ library/IDPC-Drug-Policy-Guide_Indonesia-Bahasa.pdf, diakses pada tanggal 20 Juli 2020 Pukul 20.00 WIB.

Megahartati, Tingkatan Penyalahgunaan Narkoba, https://dedihumas.bnn.go.id/read/ section/artikel/2012/08/27/526/tingkatan-penyalahgunaan-narkoba, diakses pada tanggal 24 Agustus 2020 Pukul 08.00 WIB. 